\title{
Genomic analysis of methicillin-resistant Staphylococcus aureus strain SO-1977 from Sudan
}

\author{
Mohamed S. Ali ${ }^{1} \mathbb{B}$, Nurulfiza M. Isa², Faisal M. Abedelrhman', Tahani B. Alyas ${ }^{3}$, Sara E. Mohammed", \\ Abdallah E. Ahmed', Zainab S. A. Ahmed', Nyok-Sean Lau', Mohamed I. Garbi', Abdullah Al-Ashraf Amirul', \\ Almeen O. Seed ${ }^{1}$, Rihab A. Omer ${ }^{1}$ and Sofia B. Mohamed ${ }^{1 *}$
}

\begin{abstract}
Background: Methicillin-resistant Staphylococcus aureus (MRSA) is known as a leading cause of morbidity and mortality. Investigation of the MRSA's virulence and resistance mechanisms is a continuing concern toward controlling such burdens through using high throughput whole Genome Sequencing (WGS) and molecular diagnostic assays. The objective of the present study is to perform whole-genome sequencing of MRSA isolated from Sudan using Illumina Next Generation Sequencing (NGS) platform.

Results: The genome of MRSA strain SO-1977 consists of 2,827,644 bp with 32.8\% G + C, 59 RNAs and 2629 predicted coding sequences (CDSs). The genome has 26 systems, one of which is the major class in the disease virulence and defence. A total of 83 genes were annotated to virulence disease and defence category some of these genes coding as functional proteins. Based on genome analysis, it is speculated that the SO-1977 strain has resistant genes to Teicoplanin, Fluoroquinolones, Quinolone, Cephamycins, Tetracycline, Acriflavin and Carbapenems. The results revealed that the SO-1977, strain isolated from Sudan has a wide range of antibiotic resistance compared to related strains.

Conclusion: The study reports for the first time the whole genome sequence of Sudan MRSA isolates. The release of the genome sequence of the strain SO-1977 will avail MRSA in public databases for further investigations on the evolution of resistant mechanism and dissemination of the -resistant genes of MRSA.
\end{abstract}

Keywords: Methicillin -resistance Staphylococcus aureus (MRSA), Whole genome sequencing, Antibiotic resistant genes, Genome annotation, Sudan

\section{Background}

Staphylococcus aureus (S. aureus) is a human pathogen known to cause both nosocomial and community-acquired infections [1]. It has been identified, among other classes of bacteria, resistant against some antibiotics. One of the emerged resistant strain of S. aureus is Methicillin-resistant Staphylococcus aureus (MRSA) that is the leading cause of life-threatening infections even in countries with advanced health surveillance and maintenance systems $[1,2]$. In Sudan, MRSA's

\footnotetext{
* Correspondence: Sofiabashir2002@gmail.com

${ }^{1}$ Department of Bioinformatics and Biostatistics, National University Research Institute- National University, Khartoum, Sudan

Full list of author information is available at the end of the article
}

incidence rate has increased dramatically and has been reported to be associated with wound infection constituting substantial sources of the high morbidity and mortality rate [3]. Such emergence of resistant strains is due to the overuse of not developed antibiotics that ultimately makes real challenges at treatment. Therefore, there is an urgent need to uncover the genetic basis of their virulence and resistance mechanism for better understanding as well as addressing potential effective drug targets. Over the last decades, Whole-genome sequencing (WGS) technologies witnessed large volumes of produced data including mutant genes, cancer-causing genes and genes predisposing for certain diseases. Moreover, the advanced bench-top sequencers technique,

(C) The Author(s). 2019 Open Access This article is distributed under the terms of the Creative Commons Attribution 4.0 International License (http://creativecommons.org/licenses/by/4.0/), which permits unrestricted use, distribution, and 
applied in regular clinical laboratories [4] may result in enormous diagnostic developments and challenges [5]. Genomic materials of $S$. aureus strains have been studied to understand the mechanisms and virulence factors responsible for staphylococcal antibiotic resistance. The premier $S$. aureus genomes sequenced were; MRSA strains N315 and Mu50 [6] followed by other nine strains $[7,8]$. The studies revealed that the length of staphylococcal genomes is about 2.8 Mbp with low GC content. The regions of staphylococcal genomes are well conserved, with many massive sequence blocks showing high variability [8]. Although a considerable number of the MRSA resistant to antimicrobials including Methicillin, Ofloxacin, Penicillin, Amikacin, and Vancomycin are reported in Sudan [9], the molecular investigations that help in understanding the mechanism of MRSA epidemics at the whole genome level are yet limited. The present study aims to analyse the whole genome sequence (WGS) of SO-1977 strain and subsequently evaluates the genomic diversity and genotypic prediction of the antimicrobial resistance of MRSA isolated from a patient in Sudan.

\section{Results}

\section{Genome project history}

The genome sequences of SO-1977 strain were deposited in GenBank ${ }^{\circ}$ (WGS database). The result was summarized in (Table 1).

\section{Genomic features of strain SO-1977}

As can seem from the data in Table 2, the draft genome sequence of $S$. aureus strain SO-1977 consisted of $2,827,644$ bp with a $32.8 \% \mathrm{GC}$. The number of predicted coding sequences (CDS), tRNAs and rRNAs was 2629, 51 and 4 respectively. The final assembly contained 151 contigs with N50 of 62,783 bp length. The largest contig assembled was 146,886 bp length.

Table 1 Project Information

\begin{tabular}{ll}
\hline Property & SO-1977 \\
\hline Finishing quality & Complete \\
Libraries used & $2 \times 250$ bp \\
Sequencing platforms & Illumina MiSeq \\
Fold coverage & $122.26 x$ \\
Assembly Method & SPAdes V. 3.9.0 \\
GenBank ID & NFZY00000000 \\
GenBank date of Release & 27-JUL-2017 \\
BIOPROJECT & PRJNA385553 \\
BioSample & SAMN06894057 \\
Locus Tag & CA803 \\
Source Material Identifier & Wound \\
Project relevance & Medical \\
\hline
\end{tabular}

Table 2 Nucleotide and gene content's levels of the MRSA SO1977 genome

\begin{tabular}{ll}
\hline Attribute & Value \\
\hline Genome size (bp) & $2,827,644 \mathrm{bp}$ \\
DNA G + C content & $32.8 \%$ \\
Number of Contigs & 151 \\
N50 & $62,783 \mathrm{bp}$ \\
rRNA genes & 4 \\
tRNA genes & 51 \\
ncRNAs & 4 \\
Protein-coding genes & 2629 \\
Pseudo Genes (total) & 129 \\
Pseudo Genes (frameshifted) & 62 \\
Pseudo Genes (incomplete) & 32 \\
Pseudo Genes (internal stop) & 50 \\
Pseudo Genes (multiple problems) & 13 \\
Genes assigned to SEED & 1698 \\
\hline
\end{tabular}

\section{Genome annotation using RAST (Fig. 1)}

Whole-genome annotation of MRSA strain SO-1977 on RAST server revealed a total of 1970 genes belonging to 26 subsystems such as Cofactors, Vitamins, Prosthetic Groups, Pigments, Cell Wall and Capsule and Virulence, Disease and Defense. The graphical circular map of the SO-1977 genomes was shown in Fig. 2.

\section{Genes involved in virulence, disease and defence}

Result revealed that 83 genes encoded for virulence, disease, and defence, 28 genes were annotated to be responsible for adhesion, 32 for antibiotic resistances and toxic compounds, 14 for Bacteriocins, ribosomally synthesized antibacterial peptides and 9 for invasion and intracellular resistance (Fig. 3). Some of these genes which coding functional proteins are Fibronectin binding protein, Chaperonin, Two-component response regulator BceR, Folylpolyglutamate synthase, Acetyl-coenzyme A, Carboxyl transferase beta chain, Colicin V production protein, MerR family, Multidrug resistance protein, Mercuric ion reductase and Arsenate reductase. The category of the cell wall and capsule system of peptidoglycan biosynthesis revealed that two genes have a relationship with conferring Methicillin resistance while one gene was related to Penicillin resistance.

\section{Phages, prophages, transposable elements, plasmids (Table 3)}

The analysis revealed that 35 genes are encoding for Phages, Prophages, Transposable elements, Plasmid of which 33 were annotated to be responsible for Phages, Prophages and Pathogenicity islands. 


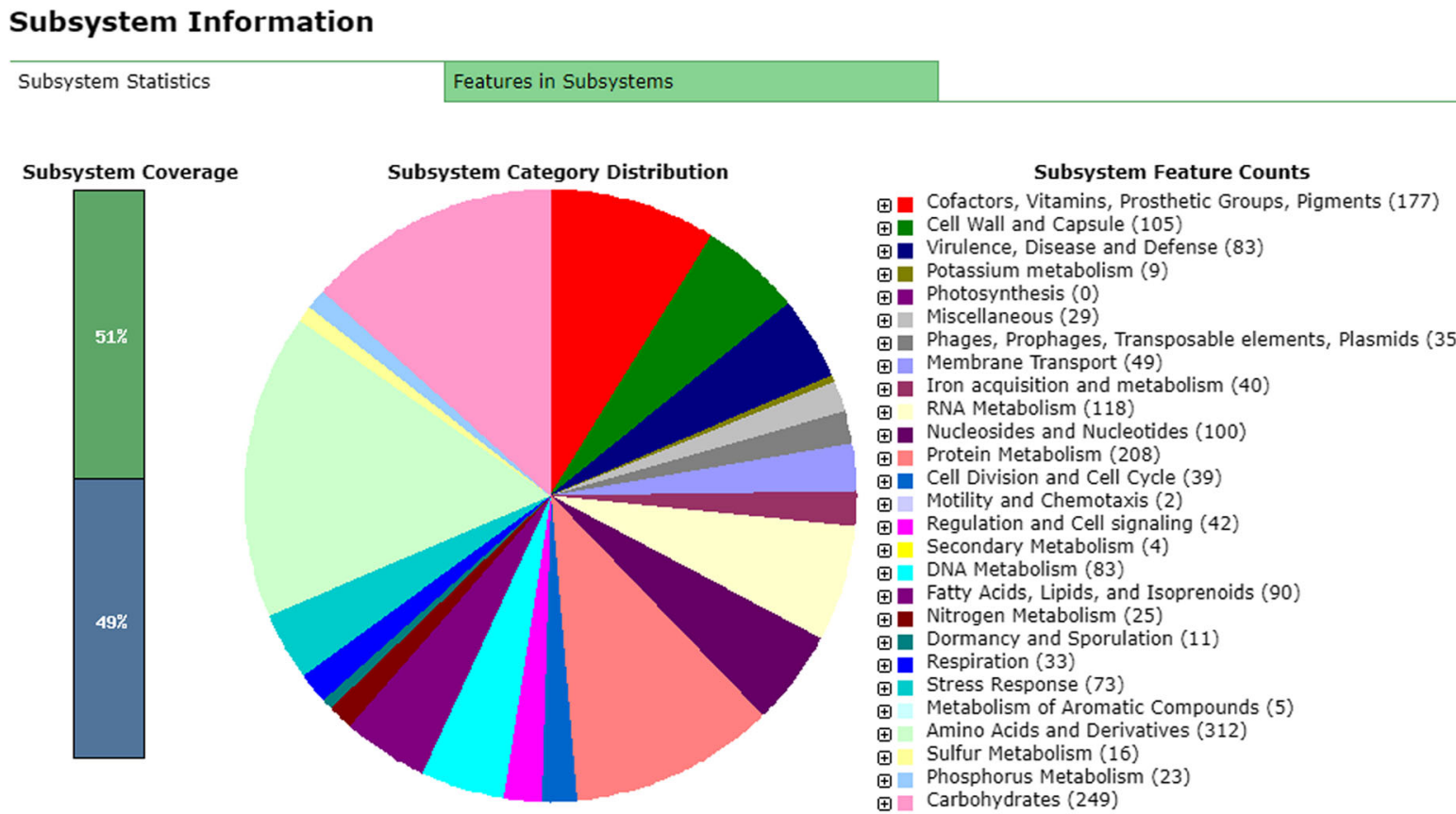

Subsystem Coverage

Subsystem Feature Counts

$\boxplus$ Cofactors, Vitamins, Prosthetic Groups, Pigments (177)

$\boxplus$ Cell Wall and Capsule (105)

$\boxplus$ Virulence, Disease and Defense (83)

(I) Potassium metabolism (9)

(1] Photosynthesis (0)

- Miscellaneous $(29)$

- Phas, Prophes, Transposable elements, Plasmids (35)

Ð1 Phages, Prophages, Trans

甲1 Iron acquisition and metabolism (40)

$\boxplus$ RNA Metabolism (118)

$\boxplus$ Nucleosides and Nucleotides (100)

由ा Protein Metabolism (208)

Tl Cell Division and Cell Cycle (39)

Motility and Chemotaxis (2)

I Regulation and Cell signaling (42)

I Regulation and Cell signaling

$\boxplus$ Secondary Metabolism

DNA Metabolism (83)

(†) Nitrogen Metabolism (25)

$\oplus$ Dormancy and Sporulation (11)

$\boxplus$ Respiration (33)

$\boxplus$ Metabolism of Aromatic Compounds (5)

$\boxplus \quad$ Amino Acids and Derivatives (312)

$\boxplus$ Sulfur Metabolism (16)

甲1 Phosphorus Metabolism (23)

由] Carbohydrates (249)

Fig. 1 Summary of annotation for MRSA strain SO-1977 based on RAST subsystem

\section{Resistant genes based comparative genomic analysis (Table 4)}

The Genome annotation and comparison results by RSAT server have shown that SO-1977 strain possesses 29 genes that may be related to multi-drug resistance and the comparison between MRSA strains was shown that 23 resistant genes were present in all strains, two genes were only found in SO-1977 strain conferring resistance against Tetracycline. Furthermore, The SO-1977 strain was the only one having the norA gene providing resistance against Quinolone beside other six genes of the family MarR. Four genes that are responsible for anti- Methicillin resistance ( $\mathrm{LytH}, \mathrm{MecI}, \mathrm{Mec}$ and MurE) were only found in MRSA252 strain. Also the results have shown that MRSA252 and MSSA476 are sharing a single common gene for anti-Methicillin resistance (HmrB).

\section{Phylogenetic analysis of nucleotide sequence of strain SO-1977}

Result on the phylogenetic of 16S rRNA (MK713975) showed that the SO-1977 strain has the highest similarity with different S. aureus strain (Table 5) (Fig. 4).

\section{Discussion}

The present study reported the first genome sequence of $S$. aureus (MRSA) isolated from Sudan to have phylogenetic allocation using the 16S rRNA gene to represent the evolutionary relationships of the bacteria. In this study, the phylogenetic analysis of the complete $16 \mathrm{~S}$ rRNA gene sequence of strain SO-1977 (MK713975) has shown that the strain should be assigned to the genus Staphylococcus. The annotated draft genome sequence of SO-1977 strain was $2827,644 \mathrm{bp}$ length containing 2629 coding sequences (CDS). Moreover, the WGS data was used to investigate antimicrobial resistance and virulence mechanism. The multi-drug resistance of this isolate might be generated by the ability of these bacteria to accumulate multiple genes on the resistance $(\mathrm{R})$ plasmids coding for a single drug resistance within a single cell or by the increased expression of genes that code for multi-drug efflux pumps, extruding a wide range of drugs [10]. In this study, S. aureus (MRSA) isolated from Sudan has been demonstrated to possess different resistance mechanisms which can be attributed to the use of resistant genes TcaR, TcaA, TcaB, TetR, TetM, PBP2a (MecA), or by secretion of enzymes (DNA gyrase subunit A, DNA gyrase subunit B, Topoisomerase IV subunit A, Topoisomerase IV subunit B and Beta-lactamase repressor) allowing it to use the efflux pump mechanism. In addition, six putative MarR family transcriptional regulators in the SO-1977 genome were identified. These were recognised as a widely conserved group of multiple antibiotic resistance regulators that respond to a wide range of antibiotics [11]. The MRSA characteristic phenotype is due to the presence of mecA, which encodes a penicillin-binding protein (PBP), 


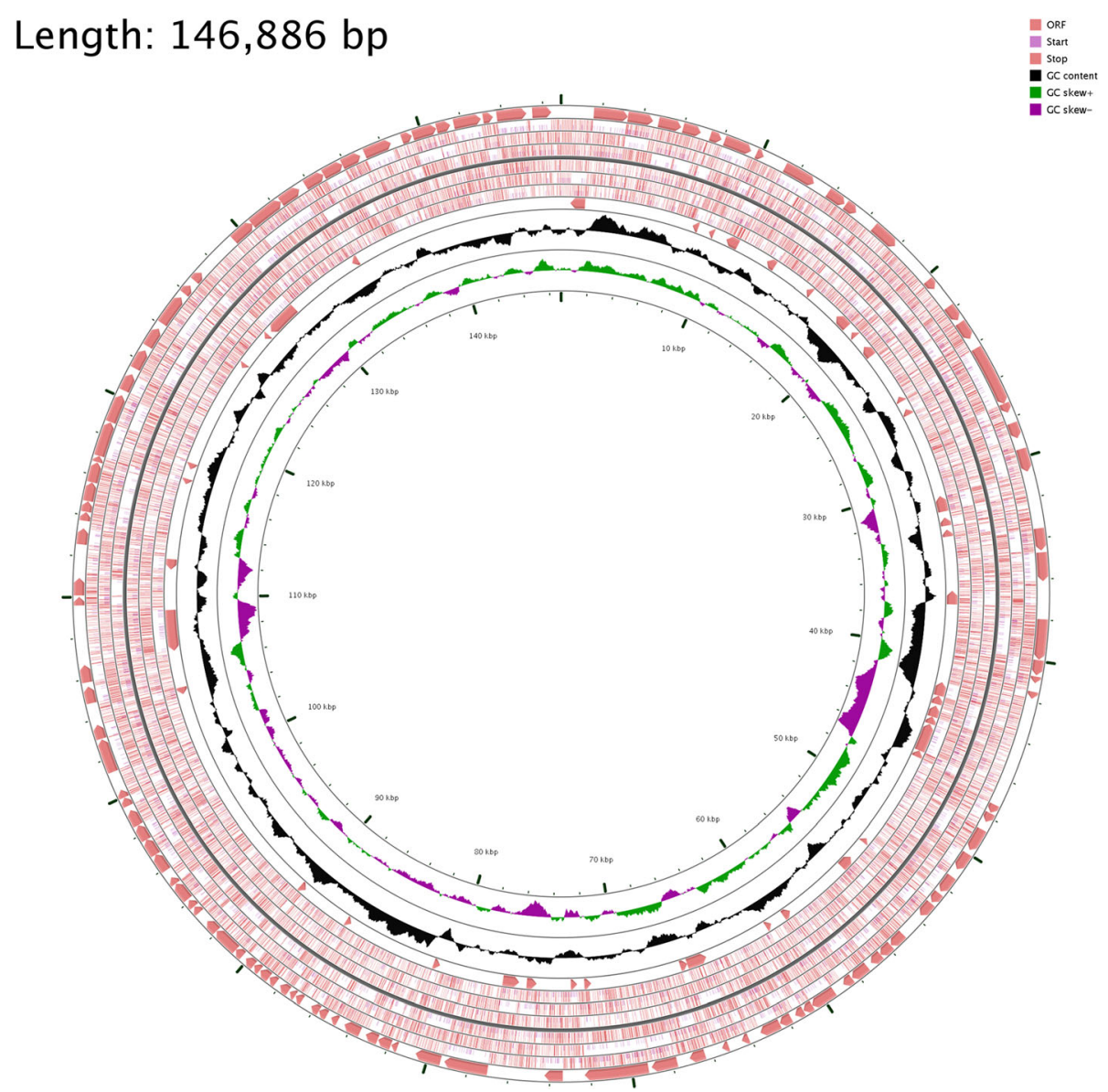

Fig. 2 Circular map of the chromosome of the S. aureus SO - 1977. The innermost ring represents the SO - 1977 chromosome. The second ring (in black) plots the $\mathrm{G}+\mathrm{C}$ content of the reference, followed by its $\mathrm{G}+\mathrm{C}$ skew (in purple/green)

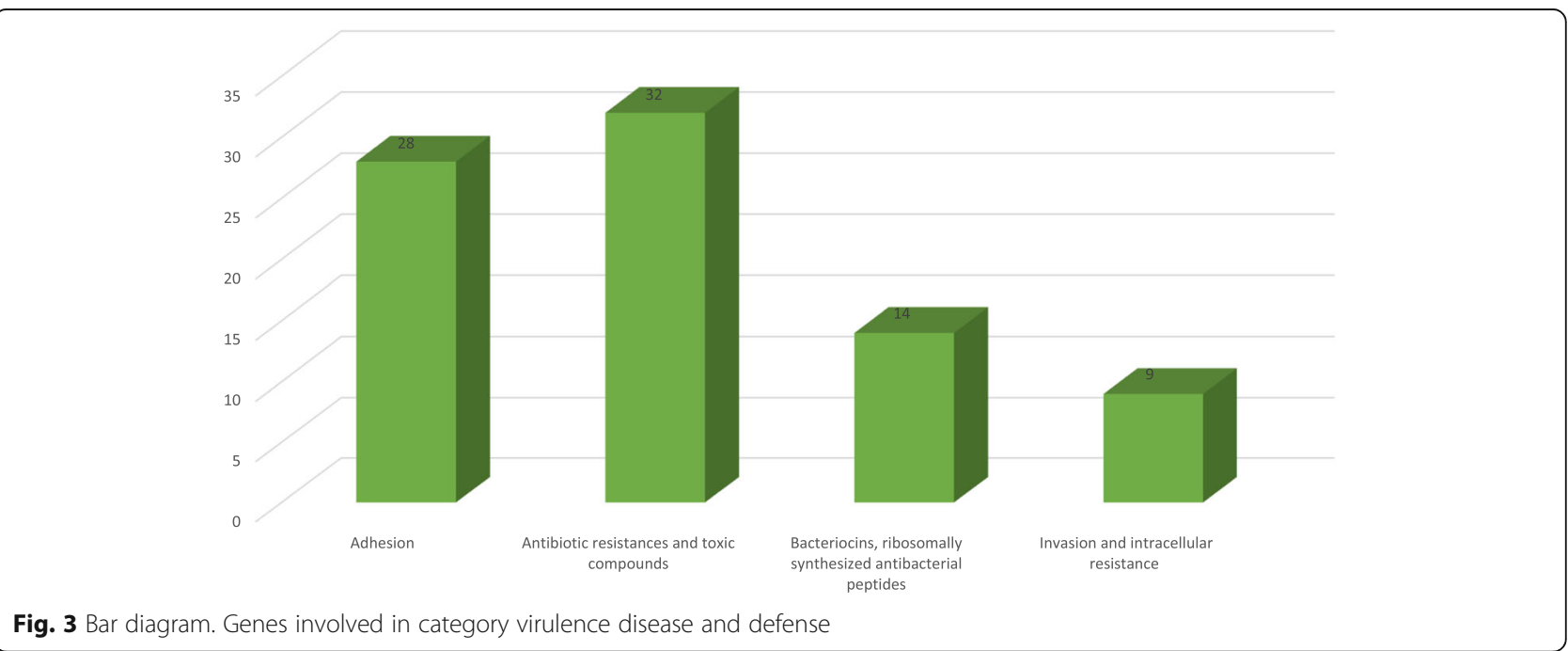

Fig. 3 Bar diagram. Genes involved in category virulence disease and defense 
Table 3 Systems included Phages, prophages, transposable elements, plasmids category

\begin{tabular}{|c|c|c|c|}
\hline Category & Subcategory & Subsystem & Role \\
\hline \multirow{7}{*}{$\begin{array}{l}\text { Phages, Prophages, } \\
\text { Transposable elements, } \\
\text { Plasmids }\end{array}$} & \multirow[t]{5}{*}{$\begin{array}{l}\text { Phages, } \\
\text { Prophages }\end{array}$} & $\begin{array}{l}\text { Phage tail } \\
\text { proteins }\end{array}$ & Phage tail protein/ Phage tail length tape-measure protein \\
\hline & & $\begin{array}{l}\text { Phage } \\
\text { replication }\end{array}$ & $\begin{array}{l}\text { Single stranded DNA-binding protein/ Phage replication initiation protein/ DNA } \\
\text { polymerase III alpha subunit/ DNA helicase, phage-associated }\end{array}$ \\
\hline & & $\begin{array}{l}\text { Phage } \\
\text { packaging } \\
\text { machinery }\end{array}$ & $\begin{array}{l}\text { Phage DNA packaging/ Phage terminase, small subunit/ Phage terminase, large } \\
\text { subunit/ Phage portal protein }\end{array}$ \\
\hline & & $\begin{array}{l}\text { Phage capsid } \\
\text { proteins }\end{array}$ & $\begin{array}{l}\text { Phage capsid and scaffold/ Phage head maturation protease/ Phage major capsic } \\
\text { protein/ Phage capsid protein }\end{array}$ \\
\hline & & $\begin{array}{l}\text { Phage lysis } \\
\text { modules }\end{array}$ & Phage lysin, N-acetylmuramoyl-L-alanine amidase/ Phage holin \\
\hline & \multirow{2}{*}{$\begin{array}{l}\text { Pathogenicity } \\
\text { islands }\end{array}$} & \multirow{2}{*}{$\begin{array}{l}\text { Listeria } \\
\text { Pathogenicity } \\
\text { Island LIPI-1 } \\
\text { extended }\end{array}$} & Phosphatidylinositol-specific phospholipase \\
\hline & & & Zinc metalloproteinase precursor \\
\hline
\end{tabular}

PBP2a, with reduced affinity for b-lactams. MecA is embedded in a large heterologous chromosomal cassette, the SCCmec element. Some MRSA strains carry upstream to the mecA gene such as the regulatory genes mecI-mecR1 that encoding for a repressor and a sensor/inducer of the mecA expression, respectively [12]. In this study, MecA and MecR1 were found in SO-1977 and MRSA252, while the mecI was found only in MRSA252. This result suggested that the existence of yet unidentified additional determinants involved in the transcriptional control of mecA gene and point to a revision of the mecA regulatory mechanism in MRSA SO-1977 strain. The antibiotic sensitivity tests demonstrated that the isolate is resistant to discsoxacillin and cefoxitin. The result of the WGS confirmed the resistance of the isolate to the antibiotics and expanded it to include Teicoplanin, Fluoroquinolones, Quinolone, Cephamycins, Tetracycline, Acriflavin and Carbapenems. Such a result should be considered while planning an effective treatment protocol. The antibiotic-resistant genes of SO-1977, MRSA252 and MSSA476 revealed that the SO-1977 strain isolated from Sudan is complicated and has a wide range of cross-antibiotic resistance.

\section{Conclusion}

The current study is the first of its kind in Sudan to give an insight of an important antibiotic resistant bacterial strain, MRSA SO-1977. The SO-1977 strain is resistant to Teicoplanin, Fluoroquinolones, Quinolone, Cephamycins, Tetracycline, Acriflavin and Carbapenems. This study strongly suggests that other yet unidentified determinants are involved directly or indirectly in the transcriptional control of the mecA gene in SO-1977 strain. The SO-1977 strain has a wide range of antibiotic resistance compared to other strains. The whole genome of SO-1977 strain can provide a genetic background of virulence, antibiotic resistance and Phages of the MRSA species in Sudan.

\section{Methods}

\section{Sample preparation}

A wound swab specimen was collected from a patient at Soba Hospital, Khartoum, and was inoculated in sheep blood agar and mannitol salt agar at $37^{\circ} \mathrm{C}$ for $24 \mathrm{~h}$. For the purpose of colonies identification, standard procedures and tests were performed including gram stain, catalase, coagulase, and DNase tests were used to identify the colonies [13]. The positive cultures for S. aureus were then suspended with a concentration similar to turbidity standard equivalent to $0.5 \%$ McFarland and streaked on Mueller-Hinton agar (MHA). Oxacillin $(6 \mu \mathrm{g} \backslash \mathrm{ml})$ and cefoxitin $(30 \mu \mathrm{g} \backslash \mathrm{ml})$ antimicrobial disc were positioned at suitable distances on the bacterial lawns on $\mathrm{MHA}$ at $33^{\circ} \mathrm{C}$ for $24 \mathrm{~h}$. The antibiotic resistance profiling of the strain against a broader range of antibiotics was not performed as a limitation of the study. The growth inhibition zones were then measured according to the standard Kirby -Bauer disc diffusion method and NCCLs guidelines using a calliper [14]. In which the revealed measurements were indicatives of resistant colonies of MRSA strain.

\section{Genomic DNA extraction and sequencing library preparation}

Bacterial DNA was extracted using Qiagen Kit following the manufacturer instructions. The concentration and purity of the resultant DNA were photo-metrically determined using a Nano-drop (Thermofisher ${ }^{\circledR}$ ). About $5 \mu \mathrm{g}$ of genomic DNA (A260/280 = 1.93) was used for library preparation and $4 \mathrm{~nm}$ of genomic DNA was used as an input for the Nextera XT kit (Illumina). Then samples were targeted for bar-coding using forward (N702) and reverse (N702) primers in 12 cycles of amplification in the PCR machine. Libraries were then quantified on the Bioanalyzer (Agilent Technologies) and combined with an equimolar mixture. Finally, $0.19 \mathrm{ng} / \mathrm{ml}$ was used 
Table 4 Summary of CDSs annotated to antibiotic resistance between SO-1977, MRSA252 and MSSA476 strains

\begin{tabular}{|c|c|c|c|c|c|c|c|}
\hline No & $\begin{array}{l}\text { SO- } \\
1977\end{array}$ & MRSA252 & MSSA476 & Seed subsystem & Seed function & $\begin{array}{l}\text { Length } \\
\text { (bp) }\end{array}$ & $\begin{array}{l}\text { Contig } \\
\text { number }\end{array}$ \\
\hline 1 & $\checkmark$ & $\checkmark$ & & Peptidoglycan Biosynthesis & $\begin{array}{l}\text { Methicillin resistance determinant } \\
\text { MecA, transpeptidase }\end{array}$ & 2007 & $\begin{array}{l}\text { Contig } \\
000034\end{array}$ \\
\hline 2 & $\checkmark$ & $\checkmark$ & $\checkmark$ & $\begin{array}{l}\text { Multidrug Resistance, 2-protein version Found in } \\
\text { Gram-positive bacteria }\end{array}$ & $\begin{array}{l}\text { Multidrug resistance protein [function } \\
\text { not yet clear] }\end{array}$ & 648 & $\begin{array}{l}\text { Contig } \\
000037\end{array}$ \\
\hline 3 & $\checkmark$ & $\checkmark$ & $\checkmark$ & $\begin{array}{l}\text { Multidrug Resistance, 2-protein version Found in } \\
\text { Gram-positive bacteria }\end{array}$ & $\begin{array}{l}\text { Membrane component of multidrug } \\
\text { resistance system }\end{array}$ & 1932 & $\begin{array}{l}\text { Contig } \\
000037\end{array}$ \\
\hline 4 & $\checkmark$ & $\checkmark$ & $\checkmark$ & $\begin{array}{l}\text { Multidrug Resistance, 2-protein version Found in } \\
\text { Gram-positive bacteria }\end{array}$ & $\begin{array}{l}\text { TetR family regulatory protein of MDR } \\
\text { cluster }\end{array}$ & 555 & $\begin{array}{l}\text { Contig } \\
000037\end{array}$ \\
\hline 5 & $\checkmark$ & & & Tetracycline resistance, ribosome protection type & Tetracycline resistance protein TetM & 1920 & $\begin{array}{l}\text { Contig } \\
000042\end{array}$ \\
\hline 6 & $\checkmark$ & & & Tetracycline resistance, ribosome protection type & Translation elongation factor $\mathrm{G}$ & 2082 & $\begin{array}{l}\text { Contig } \\
000014\end{array}$ \\
\hline 7 & $\checkmark$ & $\checkmark$ & $\checkmark$ & Teicoplanin-resistance in Staphylococcus & $\begin{array}{l}\text { Teicoplanin resistance associated } \\
\text { membrane protein TcaA }\end{array}$ & 1209 & $\begin{array}{l}\text { Contig } \\
000002\end{array}$ \\
\hline 8 & $\checkmark$ & $\checkmark$ & $\checkmark$ & Teicoplanin-resistance in Staphylococcus & $\begin{array}{l}\text { Teicoplanin resistance associated } \\
\text { membrane protein TcaB }\end{array}$ & 1383 & $\begin{array}{l}\text { Contig } \\
000002\end{array}$ \\
\hline 9 & $\checkmark$ & $\checkmark$ & $\checkmark$ & Teicoplanin-resistance in Staphylococcus & $\begin{array}{l}\text { Teicoplanin-resistance associated } \\
\text { HTH-type transcriptional regulator } \\
\text { TcaR }\end{array}$ & 456 & $\begin{array}{l}\text { Contig } \\
000002\end{array}$ \\
\hline 10 & $\checkmark$ & & & Quinolone resistance protein norA & none & 1167 & $\begin{array}{l}\text { Contig } \\
000007\end{array}$ \\
\hline 11 & $\checkmark$ & $\checkmark$ & & Bicyclomycin resistance protein $\mathrm{TcaB}$ & none & 1212 & $\begin{array}{l}\text { Contig } \\
000002\end{array}$ \\
\hline 12 & $\checkmark$ & $\checkmark$ & $\checkmark$ & Transcriptional regulator, MarR family & None & 456 & $\begin{array}{l}\text { Contig } \\
000003\end{array}$ \\
\hline 13 & $\checkmark$ & $\checkmark$ & $\checkmark$ & Transcriptional regulator, MarR family & None & 420 & $\begin{array}{l}\text { Contig } \\
000005\end{array}$ \\
\hline 14 & $\checkmark$ & $\checkmark$ & $\checkmark$ & Transcriptional regulator, MarR family & None & 210 & $\begin{array}{l}\text { Contig } \\
000043\end{array}$ \\
\hline 15 & $\checkmark$ & $\checkmark$ & $\checkmark$ & Transcriptional regulator, MarR family & None & 435 & $\begin{array}{l}\text { Contig } \\
000030\end{array}$ \\
\hline 16 & $\checkmark$ & $\checkmark$ & $\checkmark$ & Transcriptional regulator, MarR family & None & 441 & $\begin{array}{l}\text { Contig } \\
000001\end{array}$ \\
\hline 17 & $\checkmark$ & $\checkmark$ & $\checkmark$ & Transcriptional regulator,MarR family & None & 468 & $\begin{array}{l}\text { Contig } \\
000030\end{array}$ \\
\hline 18 & $\checkmark$ & $\checkmark$ & $\checkmark$ & Resistance to fluoroquinolones & DNA gyrase subunit B & 2403 & $\begin{array}{l}\text { Contig } \\
000010\end{array}$ \\
\hline 19 & $\checkmark$ & $\checkmark$ & $\checkmark$ & Resistance to fluoroquinolones & DNA gyrase subunit A & 2661 & $\begin{array}{l}\text { Contig } \\
000011\end{array}$ \\
\hline 20 & $\checkmark$ & $\checkmark$ & $\checkmark$ & Resistance to fluoroquinolones & Topoisomerase IV subunit B & 1998 & $\begin{array}{l}\text { Contig } \\
000010\end{array}$ \\
\hline 21 & $\checkmark$ & $\checkmark$ & $\checkmark$ & Resistance to fluoroquinolones & Topoisomerase IV subunit A & 2403 & $\begin{array}{l}\text { Contig } \\
000010\end{array}$ \\
\hline 22 & $\checkmark$ & $\checkmark$ & $\checkmark$ & Beta-lactamase & Beta-lactamase & 1500 & $\begin{array}{l}\text { Contig } \\
000002\end{array}$ \\
\hline 23 & $\checkmark$ & $\checkmark$ & $\checkmark$ & Beta-lactamase & Beta-lactamase repressor Blal & 381 & $\begin{array}{l}\text { Contig } \\
000067\end{array}$ \\
\hline 24 & $\checkmark$ & $\checkmark$ & $\checkmark$ & Multidrug Resistance Efflux Pumps & Acriflavin resistance protein & 3168 & $\begin{array}{l}\text { Contig } \\
000001\end{array}$ \\
\hline 25 & $\checkmark$ & $\checkmark$ & $\checkmark$ & $\begin{array}{l}\text { Multi antimicrobial extrusion protein }(\mathrm{Na}(+) / \text { drug } \\
\text { antiporter), MATE family of MDR efflux pumps }\end{array}$ & Multidrug Resistance Efflux Pumps & 1356 & $\begin{array}{l}\text { Contig } \\
000005\end{array}$ \\
\hline 26 & & $\checkmark$ & $\checkmark$ & Methicillin resistance in staphylococci & $\begin{array}{l}\text { HmrB protein involved in methicillin } \\
\text { resistance }\end{array}$ & 1600 & NC_002952 \\
\hline
\end{tabular}


Table 4 Summary of CDSs annotated to antibiotic resistance between SO-1977, MRSA252 and MSSA476 strains (Continued)

\begin{tabular}{|c|c|c|c|c|c|c|c|}
\hline No & $\begin{array}{l}\text { SO- } \\
1977\end{array}$ & MRSA252 & MSSA476 & Seed subsystem & Seed function & $\begin{array}{l}\text { Length } \\
\text { (bp) }\end{array}$ & $\begin{array}{l}\text { Contig } \\
\text { number }\end{array}$ \\
\hline 27 & $\checkmark$ & $\checkmark$ & $\checkmark$ & Methicillin resistance in staphylococci & Beta-lactamase repressor Blal & 381 & $\begin{array}{l}\text { Contig } \\
000067\end{array}$ \\
\hline 28 & $\checkmark$ & $\checkmark$ & $\checkmark$ & Methicillin resistance in staphylococci & FmhA protein of FemAB family & 1251 & $\begin{array}{l}\text { Contig } \\
000002\end{array}$ \\
\hline 29 & & $\checkmark$ & & Methicillin resistance in staphylococci & $\begin{array}{l}\text { LytH protein involved in methicillin } \\
\text { resistance }\end{array}$ & 1600 & NC_002952 \\
\hline 30 & $\checkmark$ & $\checkmark$ & & Methicillin resistance in staphylococci & $\begin{array}{l}\text { Methicillin resistance regulatory } \\
\text { sensor-transducer MecR1 }\end{array}$ & 1600 & $\begin{array}{l}\text { Contig } \\
\text { 000034/ } \\
\text { NC_002952 }\end{array}$ \\
\hline 31 & & $\checkmark$ & & Methicillin resistance in staphylococci & Methicillin resistance repressor $\mathrm{Mecl}$ & 1600 & NC_002952 \\
\hline 32 & & $\checkmark$ & & Methicillin resistance in staphylococci & $\begin{array}{l}\text { Transposase for insertion sequence- } \\
\text { like element IS431mec }\end{array}$ & 1296 & NC_002952 \\
\hline 33 & & $\checkmark$ & & Methicillin resistance in staphylococci & $\begin{array}{l}\text { UDP-N-acetylmuramoylalanyl-D- } \\
\text { glutamate--2,6-diaminopimelate ligase }\end{array}$ & 1600 & NC_002952 \\
\hline 34 & $\checkmark$ & $\checkmark$ & $\checkmark$ & Methicillin resistance in staphylococci & $\begin{array}{l}\text { Beta-lactamase regulatory sensor- } \\
\text { transducer BlaR1 }\end{array}$ & 1089 & $\begin{array}{l}\text { Contig } \\
000067\end{array}$ \\
\hline
\end{tabular}

as an input for Next-generation sequencing (NGS) and libraries were sequenced on a single run on the Illumina MiSeq instrument (250 bp paired-end reads).

\section{Bacterial genome sequencing and assembly}

Poor-quality and adaptor-containing reads were filtered and trimmed using BBTools version 36 [15]. Good quality sequencing reads were assembled using SPAdes version 3.5.0. For the prediction of tRNA and rRNA genes, ARAGORN 1.2.34 and RNAmmer1.2 were used, respectively $[16,17]$. The protein-coding genes were then predicted using Prodigal 2.60 [18] as well as their function by using BLASTN 2.2.25+ [19] and followed by detecting sequence homologs through searching for various sequence domain databases using HMMER 3.0 (http://hmmer.org/).

\section{Genome annotation}

The final draft genome sequence of S. aureus SO-1977 was used for annotation using RAST [20] and NCBI Prokaryotic Genome Annotation Pipeline [21]. The annotated genes were exported from the RAST server into an excel table and manually compared for genomic features. The antibiotic resistance genes of the $S$. aureus SO-1977, S. aureus MRSA252 (PRJNA265) and S. aureus MSSA476 (PRJNA116329) were retrieved from RAST server then the comparison was done [22]. The graphical circular map of the genomes was made by CGView server [23].

\section{Phylogenetic analysis of strain SO-1977 using 16S rRNA}

The 16S rRNA sequences were edited and assembled to a final length of $1545 \mathrm{bp}$, GenBank accession number (MK713975). All reference sequences of the 16S rRNA genes of S.aureus used in this study were obtained from GenBank $^{\bullet}$ (https://www.ncbi.nlm.nih.gov/genbank/) using the RDP 11.5, Seqmatch: version 3 (https://rdp.cme.msu. edu/). DNA sequence alignment was performed using MUSCLE v. 3.8.31 (http://www.ebi.ac.uk/Tools/msa/ muscle/) on the European Bioinformatics Institute (EBI) homepage. Once the alignment was completed, the phylogenetic tree was drowning as the evolutionary distances

Table $\mathbf{5}$ List of $16 \mathrm{~S}$ rRNA

\begin{tabular}{lll}
\hline Strain & Accession no. & Seq match \\
\hline S. aureus & L37597.1 & 1 \\
S. aureus MPU99 & AB353073.1 & 1 \\
S. aureus SA1 & AB305019.1 & 1 \\
S. aureus ATCC 14458 & DQ997837.1 & 1 \\
S. aureus subsp. anaerobius DSM 20714 & AY688031.1 & 1 \\
S. aureus K16-13 & AY859409.1 & 1 \\
S. aureus1 & AY144447.1 & 1
\end{tabular}

${ }^{\mathrm{a}}$ Seq match score, the number of (unique) 7-base oligomers shared between your sequence and a given RDP sequence divided by the lowest number of unique oligos in either of the two sequences 


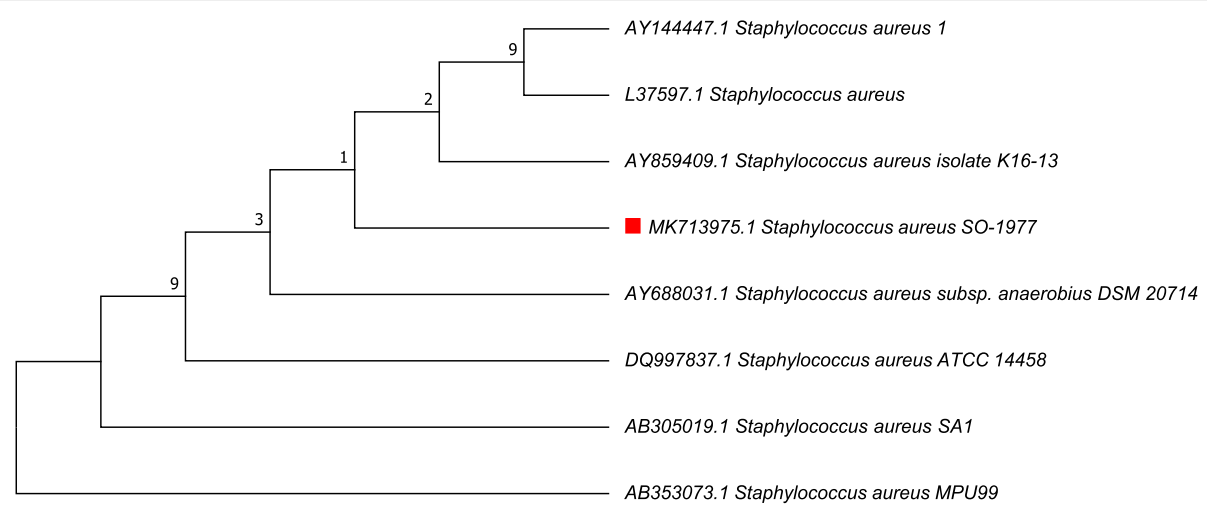

Fig. 4 Neighbour-joining tree based on 16S rRNA gene sequences showing the Phylogenetic relationship between Staphylococcus aureus strain SO-1977 relative to other type strains within the Staphylococcus aureus in database. Bootstrap values (expressed as percentages of 100 replications) less than $50 \%$ are hidden

were computed using the Maximum Likelihood method implemented in MEGA6 version 6 [24] in all positions containing gaps and missing data were eliminated.

\section{Sequence data access}

The genomic data of this study were deposited publicly in DDBJ/ENA/GenBank ${ }^{\circ}$ under Accession: NFZY00000000, BioProject: PRJNA385553 and Biosample: SAMN 06894057.

\section{Abbreviations}

CDS: Coding sequences; MRSA: Multidrug-resistant Staphylococcus aureus; NGS: Next-generation sequencing; WGS: Whole genome sequencing; RAST: Rapid Annotation using Subsystem Technology

\section{Acknowledgements}

We thank Prof. Mohamed M.A Alnour and Ms. Somyia Kambal for reviewed the manuscript. This work was supported by National University Research Institute-National University, Sudan.

\section{Funding}

This work was supported by National university research institute / National University. The funding body had a role.

\section{Availability of data and materials}

The datasets generated during the current study are available from the corresponding author publicly available due (Whole Genome Shotgun project has been deposited at DDBJ/ENA/GenBank under the accession NFZY00000000 and PRJNA385553. The version described in this paper is version NFZY01000000.

\section{Authors' contributions}

SBM, MSA and AOS planned and directed the project. SEM and MIG collected the sample, TBA, AEA, ZSAA and FMA laboratory work and bacterial identification. SBM, RAO and NMI drafted the manuscript. SBM, N-SL and AAA performed the gene annotation and comparative genomic analysis and interpreted the results. All authors read and approved the final manuscript.

\section{Ethics approval and consent to participate}

This research was approved by the Ethical Committee of the International University of Africa, Khartoum Sudan and written consent was obtained.

\section{Consent for publication}

Not applicable.

\section{Competing interests}

The authors declare that they have no competing interests.

\section{Publisher's Note}

Springer Nature remains neutral with regard to jurisdictional claims in published maps and institutional affiliations.

\section{Author details}

1Department of Bioinformatics and Biostatistics, National University Research Institute- National University, Khartoum, Sudan. ${ }^{2}$ Department of Cell and Molecular Biology, Faculty of Biotechnology and Bimolecular Sciences, Universiti Putra Malaysia, Selangor, Malaysia. ${ }^{3}$ Tropical Medicine Research Institute, Khartoum, Sudan. ${ }^{4}$ Department of microbiology, faculty of medical laboratory sciences, National University, Khartoum, Sudan. ${ }^{5}$ Centre for Chemical Biology, Universiti Sains Malaysia, 11900 Bayan Lepas, Penang, Malaysia. ${ }^{6}$ Department of Microbiology, Faculty of Medical Laboratory Science, International University of Africa, Khartoum, Sudan.

Received: 6 February 2018 Accepted: 30 April 2019

Published online: 11 June 2019

\section{References}

1. Naimi TS, LeDell KH, Boxrud DJ, Groom AV, Steward CD, Johnson SK, Besser JM, O'Boyle C, Danila RN, Cheek JE, Osterholm MT, Moore KA, Smith KE. Epidemiology and clonality of community-acquired methicillin-resistant Staphylococcus aureus in Minnesota. Clin Infect Dis. 2001. https://doi.org/10. 1086/322693.

2. Torell E, Molin D, Tano E, Ehrenborg C, Ryden C. Community-acquired pneumonia and bacteraemia in a healthy young woman caused by methicillin-resistant Staphylococcus aureus (MRSA) carrying the genes encoding Panton-valentine leukocidin (PVL). Scand J Infect Dis. 2005. https://doi.org/10.1080/00365540500348945.

3. Ahmed RA. Detection of methicillin-resistant Staphylococcus aureus associated with wound infections in Khartoum teaching hospital, Sudan. Afr J Med Sci. 2016;1 (11 suppl):1-4.

4. Didelot $X$, Bowden R, Wilson DJ, Peto TE, Crook DW. Transforming clinical microbiology with bacterial genome sequencing. Nat Rev Genet. 2012;13: 601-12 https://doi.org/10.1038/nrg3226.

5. Metzker ML. Sequencing technologies - the next generation. NatRev Genet. 2010;11:31-46 https://doi.org/10.1038/nrg2626.

6. Kuroda M, Ohta T, Uchiyama I, Baba T, Yuzawa H, Kobayashi I, Cui L, Oguchi A, Aoki K, Nagai Y, Lian J-Q, Ito T, Kanamori M, Matsumaru H, Maruyama A Murakami H, Hosoyama A, Mizutani-Ui Y, Kobayashi K, Tanaka T, Sawano T, Inoue R, Kaito C, Sekimizu K, Hirakawa K, Kuhara S, Goto S, Yabuzaki J, Kanehisa M, Yamashita A, Oshima K, Furuya K, Yoshino C, Shiba T, Hattori M, Ogasawara N, Hayashi H, Hiramatsu K. Whole genome sequencing of methicillin resistant Staphylococcus aureus. Lancet. 2001;357(9264):1225-40. 
7. Gill SR, Fouts DE, Archer GL, Mongodin EF, Deboy RT, Ravel J, Paulsen IT, Kolonay JF, Brinkac L, Beanan MRJ, Daugherty SC, Madupu R, Angiuoli SV, Durkin AS, Haft DH, Vamathevan J, Khouri H, Utterback T, Lee C, Dimitrov G, Jiang L, Qin H, Weidman J, Tran K, Kang K, Hance $\mathbb{R}$, Nelson KE, Fraser CM. Insights on evolution of virulence and resistance from the complete genome analysis of an early methicillinresistant Staphylococcus aureus strain and a biofilm producing methicillin-resistant Staphylococcus epidermidis strain. J Bacteriol. 2005: 187:2426-38. https://doi.org/10.1128/JB.187.7.2426-2438.

8. Diep BA, Gill SR, Chang RF, Phan TH, Chen JH, Davidson MG, Lin F, Lin J, Carleton HA, Mongodin EF, Sensabaugh GF, Perdreau-Remington F. Complete genome sequence of USA300, an epidemic clone of acquired methicillin-resistant Staphylococcus aureus. Lancet. 2006;367:731-9. https:// doi.org/10.1016/S0140-6736(06)68231-7.

9. Kheder SI, Ali NA, Fathelrahman Al. Prevalence and Antimicrobial Susceptibility Pattern of Methicillin Resistance Staphylococcus in a Sudanese Surgical Ward. Pharmacol Pharm. 2012;3:103-8.

10. Chambers HF, DeLeo FR. Waves of resistance: Staphylococcus aureus in the antibiotic era. Nat Rev Microbiol. 2009;7(9):629-41. https://doi.org/10.1038/nrmicro2200.

11. Li X, Lei M, Song Y, Gong K, Li L, Liang H, Jian X. Whole genome sequence and comparative genomic analysis of multidrug-resistant Staphylococcus capitis subsp. urealyticus strain LNZR-1. Gut Pathog. 2014;6:45. Published online 2014. https://doi.org/10.1186/s13099-014-0045-x.

12. Oliveira DC, de Lencastre H. Methicillin-resistance in Staphylococcus aureus is not affected by the overexpression in trans of the mecA gene repressor: a surprising observation. PLoS One. 2011;6(8):e23287. https://doi.org/10.1371/ journal.pone.0023287.

13. Bergy, Divid H, Holt JG, Krieg NR, Peter HA. Sneath, Bergy's manual of determinative bacteriology. 9th ed. Phladelphia: Lippincott Williams and Wilikins; 1994.

14. Wayne PA .Clinical and laboratory standards institute/NCCL. Performance standards for antimicrobial susceptibility $T$ testing. Sixteenth informational supplement M100-S16.: CLSI; 2006.

15. Bartels MD, Petersen A, Worning P, Nielsen JB, Larner-Svensson H, Johansen HK, Andersen LP, Jarløv JO, Boye K, Larsen AR, Westh H. Comparing wholegenome sequencing with sanger sequencing for spa 657 typing of methicillin-resistant Staphylococcus aureus. J Clin Microbiol. 2014. https://doi. org/10.1128/JCM.01979-14.

16. Bankevich A, et al. SPAdes: a new genome assembly algorithm and its applications to single-cell sequencing. J Comput Biol. 2012;19(5):455-77. https://doi.org/10.1089/cmb.2012.0021.

17. Laslett D, Bjorn C. ARAGORN, a program to detect tRNA genes and tmRNA genes in nucleotide sequences. Nucleic Acids Res. 2004;32(1):11-6. https:// doi.org/10.1093/nar/gkh152.

18. Lagesen $K$, Hallin P, Rodland EA, Staerfeldt HH, Rognes T, Ussery DW. RNammer: consistent annotation of rRNA genes in genomic sequences. Nucleic Acids Res. 2007. https://doi.org/10.1093/nar/gkm160.

19. Camacho C, et al. BLAST+: architecture and applications. BMC bioinformatics. 2009. https://doi.org/10.1186/1471-2105-10-421.

20. Hyatt D, Chen GL, Locascio PF, Land ML, Larimer FW, Hauser L. Prodigal: prokaryotic gene recognition and translation initiation site identification. BMC bioinformatics. 2010. https://doi.org/10.1186/1471-2105-11-119.

21. Aziz RK, Bartels D, Best AA, et al. The RAST server: rapid annotations using subsystems technology. BMC Genomics. 2008;9:75. https://doi.org/10.1186/ 1471-2164-9-75

22. Tatusova T, DiCuccio M, Badretdin A, et al. NCBI prokaryotic genome annotation pipeline. Nucleic Acids Res. 2016;44(14):6614-24. https:/doi.org/10.1093/nar/gkw569.

23. Grant JR, Stothard P. The CGView server: a comparative genomics tool for circular genomes. Nucleic Acids Res. 2008. https://doi.org/10.1093/nar/gkn179.

24. Tamura K, Stecher G, Peterson D, Filipski A, Kumar S. MEGA6: molecular evolutionary genetics analysis version 6.0. Mol Biol Evol. 2013. https://doi. org/10.1093/molbev/mst197.

Ready to submit your research? Choose BMC and benefit from:

- fast, convenient online submission

- thorough peer review by experienced researchers in your field

- rapid publication on acceptance

- support for research data, including large and complex data types

- gold Open Access which fosters wider collaboration and increased citations

- maximum visibility for your research: over $100 \mathrm{M}$ website views per year

At BMC, research is always in progress.

Learn more biomedcentral.com/submissions 